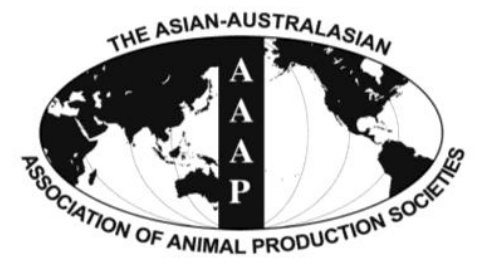

Asian-Aust. J. Anim. Sci.

Vol. 25, No. 12 : 1712-1720 December 2012

http://dx.doi.org/10.5713/ajas.2012.12279

www.ajas.info

pISSN 1011-2367 elSSN 1976-5517

\title{
The Effect of Body Energy Reserve Mobilization on the Fatty Acid Profile of Milk in High-yielding Cows
}

\author{
Zenon Nogalski*, Marek Wroński, Monika Sobczuk-Szul, Magdalena Mochol and Paulina Pogorzelska \\ University of Warmia and Mazury in Olsztyn, Department of Cattle Breeding and Milk Quality Evaluation, \\ Oczapowskiego 5, 10-719 Olsztyn, Poland
}

\begin{abstract}
We investigated the effect of the amount of body condition loss in the dry period and early lactation in 42 high-yielding Holstein-Friesian cows on milk yield and the share of fatty acids in milk fat. Energy reserves were estimated based on the body condition scoring (BCS) and backfat thickness (BFT). Milk yield and milk composition were determined over 305-d lactation. From d 6 to 60 of lactation, the concentrations of 43 fatty acids in milk fat were determined by gas chromatography. Cows were categorized based on body condition loss from the beginning of the dry period to the lowest point of the BCS curve in early lactation into three groups: low condition loss group $(\mathrm{L}) \leq 0.5$ points $(\mathrm{n}=14)$; moderate condition loss group $(\mathrm{M}) 0.75$ to 1.0 points $(\mathrm{n}=16)$ and high condition loss group $(\mathrm{H})>1.0$ points $(\mathrm{n}=12)$. Cows whose body energy reserves were mobilized at $0.8 \mathrm{BCS}$ and $11 \mathrm{~mm}$ BFT, produced $12,987 \mathrm{~kg}$ ECM over 305-d lactation, i.e. 1,429 kg ECM more than cows whose BCS and BFT decreased by 0.3 and 5 mm, respectively. In group $\mathrm{H}$, milk yield reached 12,818 kg ECM at body fat reserve mobilization of $1.3 \mathrm{BCS}$ and $17 \mathrm{~mm}$ BFT. High mobilization of body fat reserves led to a significant (approx. 5\%) increase in the concentrations of monounsaturated fatty acids-MUFA (mostly $\mathrm{C}_{18: 1}$ cis-9, followed by $\mathrm{C}_{18: 1}$ trans-11), a significant decrease in the levels of fatty acids adversely affecting human health, and a drop in the content of linoleic acid, arachidonic acid and docosahexaenoic acid in milk fat. In successive weeks of lactation, an improved energy balance contributed to a decrease in the concentrations of unsaturated fatty acids (UFA) and an increase in the conjugated linoleic acid (CLA) content of milk fat. (Key Words: Dairy Cows, Body Condition Loss, Backfat Thickness, Oleic Acid, CLA)
\end{abstract}

\section{INTRODUCTION}

Intensive genetic selection has resulted in dairy cows that yield large amounts of milk in early lactation while mobilizing body reserves extensively. The cow's milk output increases faster than its feed intake capacity, reaching their maxima 4 to 7 wks and 8 to 22 wks after calving, respectively (Ingvartsen, 2006). Negative energy balance (NEB) is partially caused by reduced dry matter intake around the time of calving. The rate and amount of changes in body condition score (BCS) and backfat thickness are good indicators of body energy reserve mobilization in early lactation (Grummer et al., 2004; Schroeder and Staufenbiel, 2006; Berry et al., 2007; Nogalski and Górak, 2008; Ayres et al., 2009). Energy stores are, therefore, a key component of milk production. Research in this area has implicated increased milk production with increased activity of lipolytic enzymes in

\footnotetext{
* Corresponding Author: Zenon Nogalski. Tel: +48-89-5233823, Fax: +48-89-5234413, E-mail: zena@uwm.edu.pl Submitted May 20, 2012; Accepted Aug. 7, 2012; Revised Aug. 21, 2012
}

adipose tissue, and more recently with greater expression of genes involved in body fat mobilization (Sumner and McNamara, 2007).

Milk fat is the main energy component of milk and the most easily digested animal fat in the human diet. Milk fat contains 400 to around 500 fatty acids (Reklewska et al., 2002). Due to its high content of saturated fatty acids and the presence of cholesterol, milk fat is considered a risk factor for atherosclerosis by some doctors and dieticians. However, it remains a rich source of many fatty acids (FA) known for their health-promoting properties (Reklewska et al., 2002; Khanal and Dhiman, 2007). Milk FA originate from four major pathways: directly from the diet, de novo synthesis in the mammary gland, formation in the rumen by biohydrogenation or bacterial degradation, and release from body fat stores (Stoop et al., 2009). Changes in milk fat composition over lactation imply shifts in the activity of these pathways and are related to changes in the energy status of the cow (Gross et al., 2011). Van Knegsel et al. (2005) suggested that during NEB, de novo synthesis of FA (C6:0 to C14:0) was reduced and body fat reserves used. 
Lactation stage and energy balance significantly contribute to variation in milk fat composition and alter the activity of different fatty acid pathways. The majority of studies conducted to date have focused on cattle herds with an average milk yield of up to $10,000 \mathrm{~kg}$. Therefore, it seems interesting to determine whether milk production and the fatty acid profile of milk from high-yielding cows are affected by NEB.

The objective of this study was to investigate the effect of the amount of body reserve loss in the dry period and early lactation in high-yielding cows on milk yield and the fatty acid profile of milk fat.

\section{MATERIALS AND METHODS}

\section{Cows}

A total of 42 animals from a herd of 330 HolsteinFriesian cows were selected for the experiment based on the following criteria: a similar calving date to eliminate the effect of calving season (the selected cows calved between 16 January 2008 and 14 March 2008), yield for the previous lactation (not lower than 10,000 kg of milk during 305-d lactation), for heifers-yield estimated based on pedigree information, lactation number-proportionally for the entire herd (first lactation 15 cows, second lactation 15 cows and third lactation 12 cows). A herd of cows kept in a free-stall system was investigated in this experiment. The cows were milked in a parallel parlor three times a day. The animals were fed a total mixed ration (TMR) based on maize silage, grass and alfalfa haylage, and brewer's spent grain. In the complete diet, the concentrate was supplemented with protein, minerals, vitamins and milk production enhancers (protein and rumen-protected fat, active yeast cultures and other energy supplements). Cows were fed a TMR formulated to produce 45 to $50 \mathrm{~L}$ of milk $(7.15 \mathrm{MJ} / \mathrm{kg}$ net energy (lactation) and $18 \%$ crude protein). Dry cows and heifers on pre-calving days 60 to 45 were kept in deep litter free-stall facilities, and they were divided into two groups: i) dry cows: 6 to $8 \mathrm{wks}$ ap (ante partum) to $3 \mathrm{wks}$ ap; ii) transition cows: 3 wks ap to $1 \mathrm{wk}$ pp (post partum). Dry cows were fed a TMR of grass and straw haylage supplemented with minerals in the dry period. Transition cows were administered lactation rations with an increasing share of concentrate. Feed was offered twice daily, using mixer wagons, and it was gathered up several times per day to ensure ad libitum access.

\section{Study design and measurements}

Energy reserves were estimated based on the body condition scoring (BCS) scale of 1 (thin) to 5 (obese) points with 0.25 intervals (Wildman et al., 1982), and backfat thickness (BFT). Ultrasound measurements of BFT were performed with the use of the Mysono 201 device (Medison
Co.) equipped with a convex probe operating in the 2 to 5 $\mathrm{MHz}$ frequency range, in the area between the ischial tuberosity, the coxal tuber and the sacrum. Prior to the measurements, the skin was shaved and covered with gel. Evaluations were carried out at two-week intervals, from 5 wks ap to 20 wks pp. Milk yield in kg ECM and the average content of fat and protein over 305-d lactation were calculated for each cow, as follows.

Energy corrected milk: milk with a standardized energy content (Sjaunja et al., 1990),

$$
\begin{aligned}
& \operatorname{ECM}(\mathrm{kg}) \\
& =\operatorname{milk}(\mathrm{kg}) \frac{(0.383 \cdot \operatorname{fat}(\%)+0.242 \cdot \operatorname{protein}(\%)+0.7832)}{3.140}
\end{aligned}
$$

Between lactation days 6 and 60, at five-day intervals, milk samples were collected from clinically healthy cows during morning milking. The proximate chemical composition of milk was determined by infrared spectrophotometry, using the Milco-scan 133 B analyzer (Foss Electric). Milk fat was extracted by the method proposed by Röse Gottlieb (AOEC, 1990), and the concentrations of 43 fatty acids were determined by gas chromatography, in the Varian CP 3800 chromatograph equipped with a split/splitless injector and a flameionization detector (FID). One $\mu$ l ester samples were placed on a capillary column with a length of $100 \mathrm{~m}$ and an internal diameter of $0.25 \mathrm{~mm}$, with the $\mathrm{CP}$-sil88 stationary phase. Helium was used as the carrier gas, injector temperature was $260^{\circ} \mathrm{C}$, and the total time of a single analysis was $68 \mathrm{~min}$. The fatty acids and fatty acid groups analyzed in the study are presented in Table 1 .

In the herd, regular health examinations were performed by the same investigator once a week. Animal handling and sampling procedures performed for the needs of this study have been fully approved by the local ethics committee in Olsztyn, Poland.

\section{Statistical analysis}

The results were processed using Statistica 9.0 software (Statsoft 2010). The experimental factor was the amount of body condition loss from the beginning of the dry period to the lowest point of the BCS curve in early lactation. Cows were categorized based on body condition loss into three groups: low condition loss group ( $\mathrm{L}) \leq 0.5$ points $(\mathrm{n}=14$ ); moderate condition loss group (M) 0.75 to 1.0 points $(\mathrm{n}=$ 16) and high condition loss group $(H)>1.0$ points $(n=12)$. The effect of body condition loss on milk yield and the share of fatty acids in milk fat was evaluated by the least squares analysis of variance, according to the below model:

$$
\mathrm{Y}_{\mathrm{ij}}=\mu+\mathrm{A}_{\mathrm{i}}+\mathrm{e}_{\mathrm{ij}}
$$


Table 1. The fatty acids and fatty acid groups analyzed in the study

\begin{tabular}{|c|c|}
\hline Groups of fatty acids & Fatty acids included \\
\hline SCFA & $\mathrm{C} 4$ to $\mathrm{C} 10$ \\
\hline MCFA & $\mathrm{C} 11$ to $\mathrm{C} 17$ \\
\hline LCFA & $\mathrm{C} 18$ to $\mathrm{C} 22$ \\
\hline SFA & C 4:0, C 6:0, C 7:0, C 8:0, C 10:0, C 11:0, C 12:0, C 13:0, C 14:0, C 15:0, C 16:0, C 17:0 \\
\hline UFA & 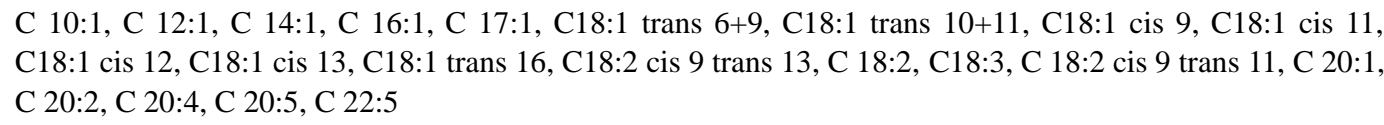 \\
\hline MUFA & 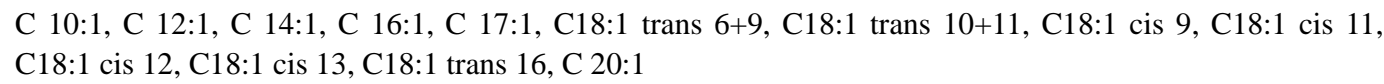 \\
\hline PUFA & $\mathrm{C} 18: 2$ cis 9 trans $13, \mathrm{C} 18: 2, \mathrm{C} 18: 3, \mathrm{C} 18: 2$ cis 9 trans 11 , C 20:2, C 20:4, C 20:5, C 22:5 \\
\hline CLA & C $18: 2$ cis 9 trans 11 \\
\hline $\mathrm{n}-3$ & C $18: 3$, C $20: 5$ \\
\hline$n-6$ & C $18: 2$, C $20: 4$ \\
\hline $\mathrm{NE}$ & C 12:0, C 14:0, C 16:0, \\
\hline
\end{tabular}

SCFA = Short-chain fatty acids; MCFA = Medium-chain fatty acids; LCFA = Long-chain fatty acids; SFA = Saturated fatty acids. UFA = Unsaturated fatty acids; MUFA = Monounsaturated fatty acids; PUFA = Polyunsaturated fatty acids.

$\mathrm{CLA}=$ Conjugated linoleic acid; $\mathrm{NE}=$ Acids with a negative effect on human health.

where:

$Y_{i j}=$ values of the analyzed parameters

$\mu=$ population mean

$\mathrm{A}_{\mathrm{i}}=$ effect of the $\mathrm{i}^{\text {th }}$ body condition loss

$\mathrm{e}_{\mathrm{ij}}=$ random error.

Differences between means were estimated using Tukey's test.

\section{RESULTS}

The depth and length of the NEB phase are illustrated by changes in the BCS profile and BFT (Figure 1). Cows with a higher BCS in the dry period were characterized by more intense fat reserve mobilization. Between $5 \mathrm{wks}$ ap to the point of the lowest BCS, i.e. until wk $9 \mathrm{pp}$, the body condition of group $\mathrm{H}$ cows deteriorated by 1.3 points on average, which corresponded to an average change of 17 $\mathrm{mm}$ in BFT. In group H cows, intense mobilization of fat reserves began already at the end of the dry period. During the dry period and in the first three weeks of lactation, changes in their BCS exceeded 1 point. In cows whose BCS decreased to a lower degree, the energy demand and dietary energy intake were already balanced in wk $5 \mathrm{pp}$ (group L).

In group $\mathrm{M}$, the average total output over 305-d lactation was 12,987 kg ECM (Table 2). The difference between groups $\mathrm{Ma}$ and $\mathrm{L}$ was significant, at $1,429 \mathrm{~kg}$ $(\mathrm{p}<0.05)$. At peak lactation, the daily milk yield was 50 to $55 \mathrm{~kg}$ (Figure 2). The fat content of milk was very high in the first weeks of lactation, and it continued to decrease from wk 4. Milk fat concentrations until d 60 of lactation and the average fat content of milk during 305-d lactation were higher in cows intensively mobilizing their body fat

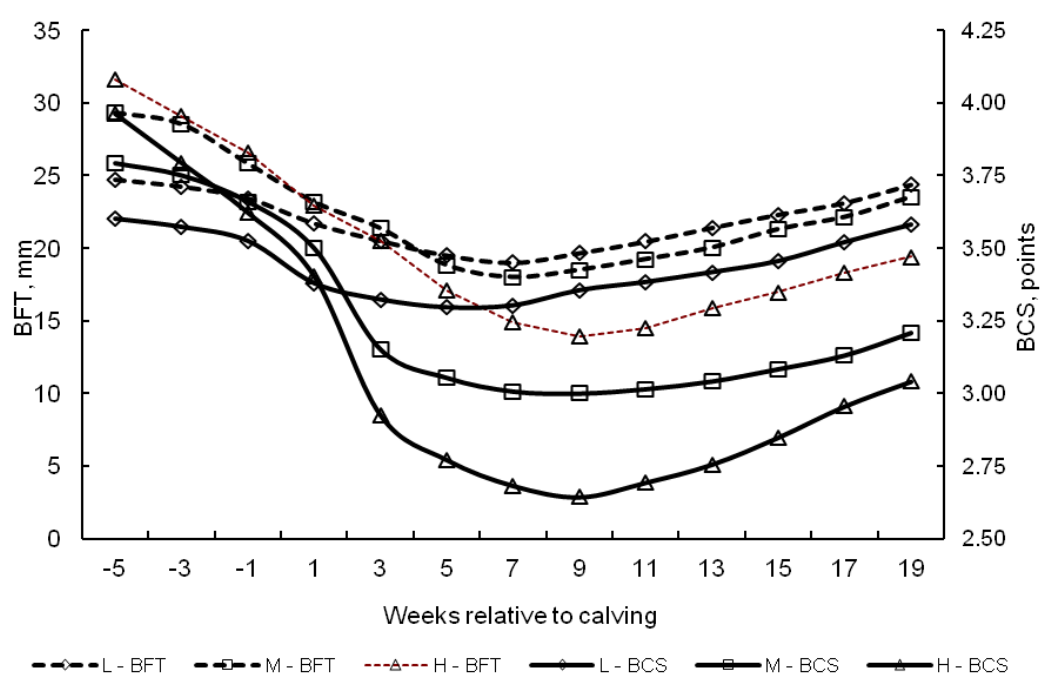

Figure 1. Changes in the body condition score (BCS) and backfat thickness (BFT) of cows in the dry period and early lactation. L = Low condition loss, $\mathrm{M}=$ Moderate condition loss, $\mathrm{H}=$ High condition loss. 
Table 2. Characteristics of 305-d lactation (Means \pm SE)

\begin{tabular}{lccc}
\hline Parameter & $\begin{array}{c}\text { Low condition loss group } \\
(\mathrm{n}=14)\end{array}$ & $\begin{array}{c}\text { Moderate condition loss group } \\
(\mathrm{n}=16)\end{array}$ & $\begin{array}{c}\text { High condition loss group } \\
(\mathrm{n}=12)\end{array}$ \\
\hline ECM $(\mathrm{kg})$ & $11,558 \pm 330.3^{\mathrm{a}}$ & $12,987 \pm 403.4^{\mathrm{b}}$ & $12,818 \pm 304.2^{\mathrm{b}}$ \\
Fat $(\%)$ & $4.13 \pm 0.07$ & $4.16 \pm 0.08$ & $4.21 \pm 0.07$ \\
Protein $(\%)$ & $3.27 \pm 0.03$ & $3.23 \pm 0.04$ & $3.22 \pm 0.03$ \\
\hline
\end{tabular}

$\overline{\mathrm{A}, \mathrm{b}} \mathrm{p} \leq 0.05$.

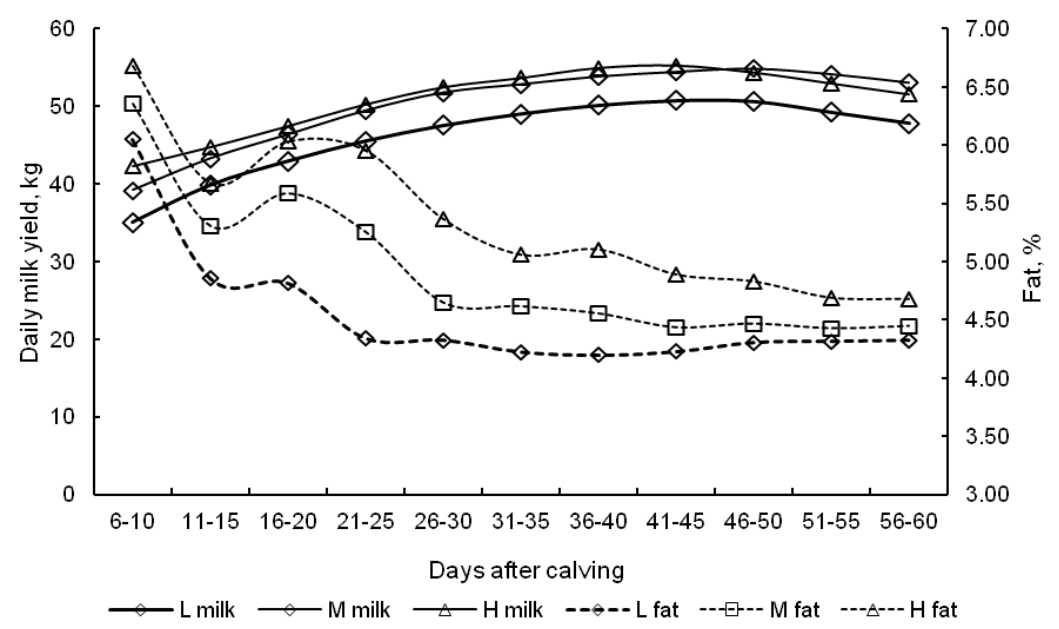

Figure 2. Changes in the daily yield and the fat content of milk in early lactation. $\mathrm{L}=$ Low condition loss, $\mathrm{M}=\mathrm{Moderate}$ condition loss, $\mathrm{H}=$ High condition loss.

reserves. The protein content of milk was highest in group $\mathrm{L}$ cows, but the noted differences were statistically nonsignificant (Table 2).

The rate of body energy reserve mobilization had a significant effect of the fatty acid profile of milk fat during the first two months of lactation (Table 3). Milk fat in group $\mathrm{L}$ cows had a significantly higher proportion of short-chain fatty acids and medium-chain fatty acids, and a lower proportion of long-chain fatty acids, compared with milk fat in the other groups. Most UFA are LCFA, which is why UFA concentrations were significantly $(p<0.01)$ lower in group L. The difference in the levels of MUFA, in particular oleic acid, exceed $5 \mathrm{~g} / 100 \mathrm{~g}$ total fat, in comparison with groups $\mathrm{M}$ and $\mathrm{H}$ (Figure 3). UFA had the highest share of the total fatty acid pool in the second week of lactation (Figure 4), and their proportion decreased on successive days. The n-3 fatty acid content of milk fat was significantly higher in group L cows, compared with the remaining groups, and it increased slightly with the progress of lactation (Figure 5).

The concentrations of functional fatty acids in milk were significantly influenced by the amount and rate of

Table 3. The effect of body condition loss from d 6 to 60 of lactation on the concentrations of selected fatty acid groups in milk fat

\begin{tabular}{|c|c|c|c|c|c|c|}
\hline \multirow{2}{*}{ Fatty acid $\mathrm{g} / 100 \mathrm{~g}$ milk fat } & \multicolumn{2}{|c|}{ Low condition loss $(\mathrm{L})$} & \multicolumn{2}{|c|}{ Moderate condition loss (M) } & \multicolumn{2}{|c|}{ High condition loss $(\mathrm{H})$} \\
\hline & LSM & SE & LSM & SE & LSM & SE \\
\hline$\overline{\text { SFCA }}$ & $7.97^{\mathrm{A}}$ & 0.183 & $7.07^{\mathrm{B}}$ & 0.162 & $7.09^{\mathrm{B}}$ & 0.205 \\
\hline MCFA & $45.53^{\mathrm{a}}$ & 0.645 & $43.18^{\mathrm{b}}$ & 0.560 & $43.12^{\mathrm{b}}$ & 0.614 \\
\hline LCFA & $46.50^{\mathrm{a}}$ & 0.851 & $49.75^{\mathrm{b}}$ & 0.705 & $49.73^{\mathrm{b}}$ & 0.772 \\
\hline SFA & $63.20^{\mathrm{A}}$ & 0.721 & $58.27^{\mathrm{B}}$ & 0.647 & $58.18^{\mathrm{B}}$ & 0.758 \\
\hline UFA & $36.79^{\mathrm{A}}$ & 0.772 & $41.73^{\mathrm{B}}$ & 0.654 & $41.76^{\mathrm{B}}$ & 0.753 \\
\hline MUFA & $32.78^{\mathrm{A}}$ & 0.725 & $37.56^{\mathrm{B}}$ & 0.638 & $37.53^{\mathrm{B}}$ & 0.705 \\
\hline PUFA & 4.14 & 0.122 & 4.17 & 0.113 & 4.23 & 0.158 \\
\hline$n-3$ & $0.40^{\mathrm{a}}$ & 0.009 & $0.37^{\mathrm{b}}$ & 0.006 & $0.36^{\mathrm{b}}$ & 0.009 \\
\hline$n-6$ & 2.57 & 0.047 & 2.50 & 0.028 & 2.47 & 0.048 \\
\hline$n-6 / n-3$ & 6.46 & 0.092 & 6.75 & 0.142 & 6.85 & 0.101 \\
\hline
\end{tabular}

Means within a row with different superscripts differ. ${ }^{\mathrm{A}, \mathrm{B}} \mathrm{p} \leq 0.01 ;{ }^{\mathrm{a}, \mathrm{b}} \mathrm{p} \leq 0.05$.

SCFA = Short-chain fatty acids; MCFA = Medium-chain fatty acids; LCFA = Long-chain fatty acids; SFA = Saturated fatty acids .

UFA $=$ Unsaturated fatty acids; MUFA = Monounsaturated fatty acids; PUFA = Polyunsaturated fatty acids . 


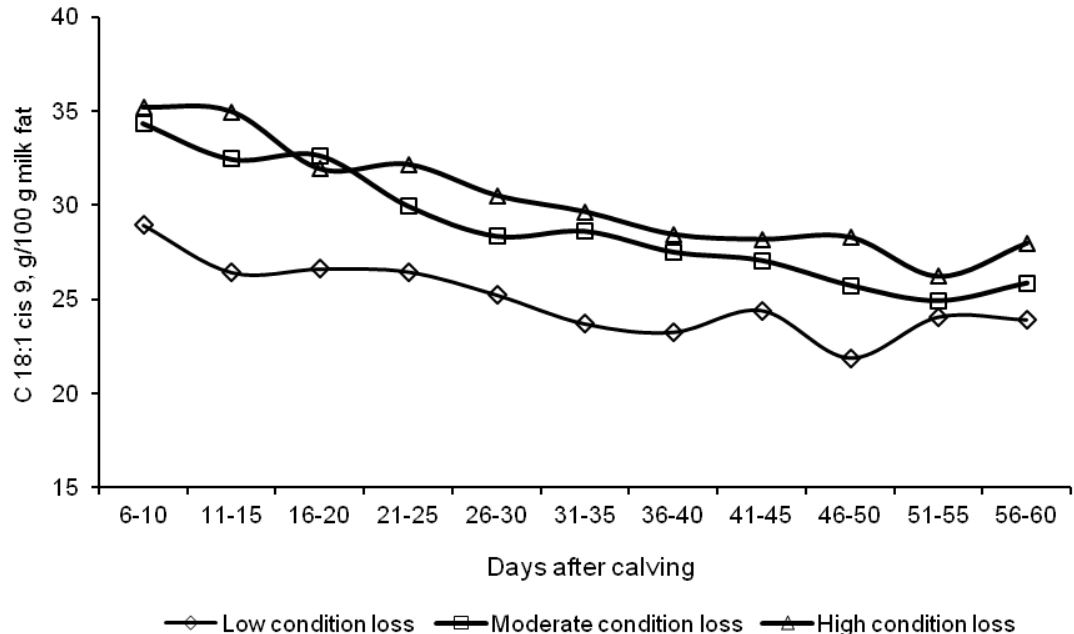

Figure 3. Changes in the oleic acid (C 18:1 cis 9) content of milk fat from d 6 to 60 of lactation.

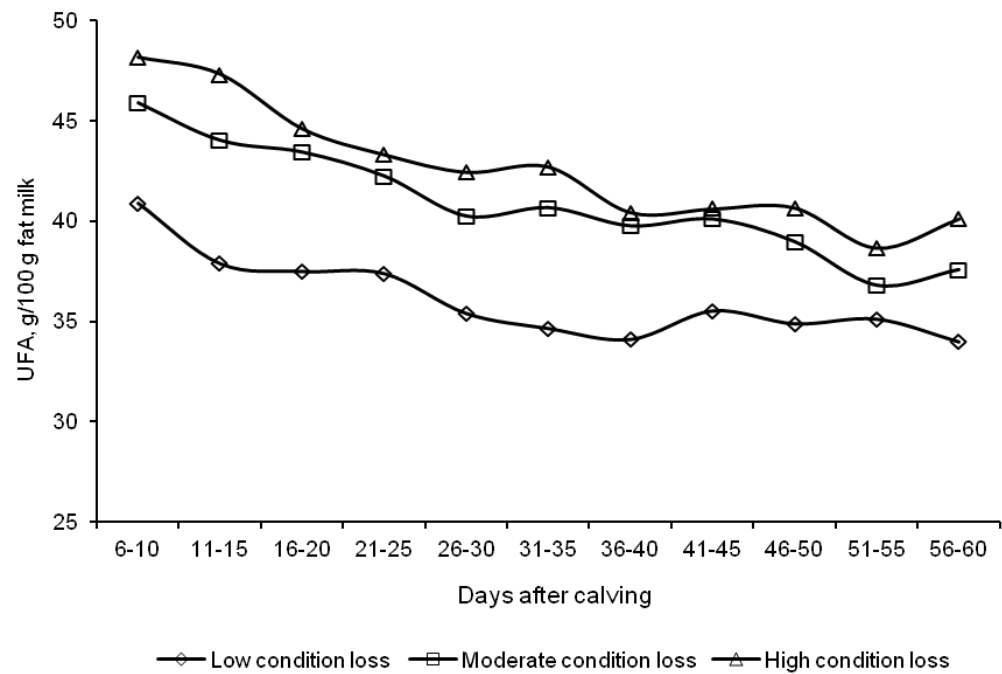

Figure 4. Changes in the unsaturated fatty acid (UFA) content of milk fat from d 6 to 60 of lactation.

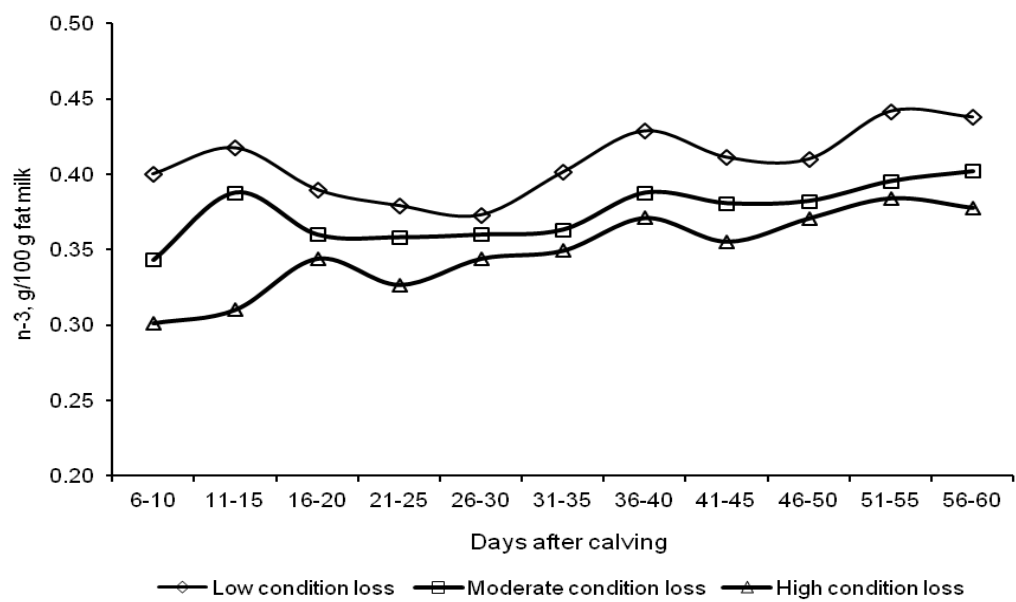

Figure 5. Changes in the n-3 fatty acid content of milk fat from d 6 to 60 of lactation. 
Table 4. The concentrations of functional fatty acids in milk fat from d 6 to 60 of lactation

\begin{tabular}{|c|c|c|c|c|c|c|}
\hline \multirow{2}{*}{ Fatty acid $\mathrm{g} / 100 \mathrm{~g}$ milk fat } & \multicolumn{2}{|c|}{ Low condition loss $(\mathrm{L})$} & \multicolumn{2}{|c|}{ Moderate condition (M) loss } & \multicolumn{2}{|c|}{ High condition loss $(\mathrm{H})$} \\
\hline & LSM & SE & LSM & SE & LSM & SE \\
\hline$\overline{\mathrm{C} 4: 0(\mathrm{BA})}$ & 2.931 & 0.053 & 2.799 & 0.043 & 2.839 & 0.066 \\
\hline C $18: 1$ trans 11 (TVA) & $1.038^{\mathrm{Aa}}$ & 0.036 & $1.188^{\mathrm{A}}$ & 0.024 & $1.132^{\mathrm{b}}$ & 0.030 \\
\hline C $18: 1$ cis $(\mathrm{OA})$ & $25.53^{\mathrm{A}}$ & 0.687 & $29.43^{\mathrm{B}}$ & 0.653 & $29.68^{\mathrm{B}}$ & 0.677 \\
\hline C $18: 2$ (LA) & 2.392 & 0.044 & 2.356 & 0.028 & 2.312 & 0.048 \\
\hline C $18: 2$ cis 9 trans 11 (CLA) & 0.357 & 0.013 & 0.335 & 0.010 & 0.347 & 0.012 \\
\hline C $18: 3$ (LNA) & $0.357^{\mathrm{Aa}}$ & 0.008 & $0.335^{\mathrm{b}}$ & 0.006 & $0.322^{\mathrm{B}}$ & 0.008 \\
\hline C 20:4 (AA) & $0.176^{\mathrm{A}}$ & 0.007 & $0.145^{\mathrm{B}}$ & 0.004 & 0.160 & 0.008 \\
\hline C $20: 5$ (EPA) & 0.043 & 0.003 & 0.036 & 0.002 & 0.041 & 0.003 \\
\hline C 22:6 (DHA) & $0.076^{\mathrm{A}}$ & 0.003 & $0.059^{\mathrm{B}}$ & 0.002 & $0.065^{\mathrm{B}}$ & 0.003 \\
\hline
\end{tabular}

Means within a row with different superscripts differ. ${ }^{\mathrm{A}, \mathrm{B}} \mathrm{p} \leq 0.01 ;{ }^{\mathrm{a}, \mathrm{b}} \mathrm{p} \leq 0.05$.

$\mathrm{BA}=$ Butyric acid; TVA = Trans-vaccenic acid; OA = Oleic acid; LA = Linoleic acid; CLA = Conjugated linoleic acid.

LNA = Linolenic acid; AA = Arachidonic acid; EPA = Eicosapentaenoic acid; DHA = Docosahexaenoic acid

body energy reserve mobilization (Table 4). The content of body fat reserve mobilization in early lactation had no short-chain butyric acid in milk was higher in group L than significant effect on the CLA content of milk, which was in the other groups, and it oscillated around $2.9 \mathrm{~g} / 100 \mathrm{~g}$ found to increase in successive weeks along with an total fat throughout the experiment (Figure 6). The rate of increase in daily milk yield (Figure 7). The concentrations

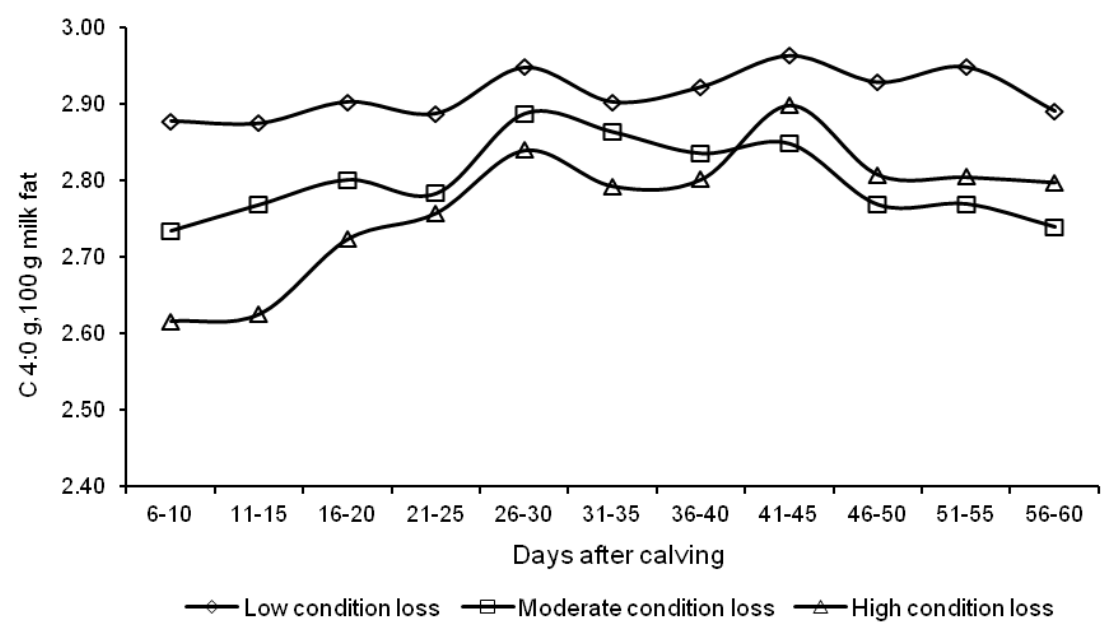

Figure 6. Changes in the butyric acid (C 4:0) content of milk fat from d 6 to 60 of lactation.

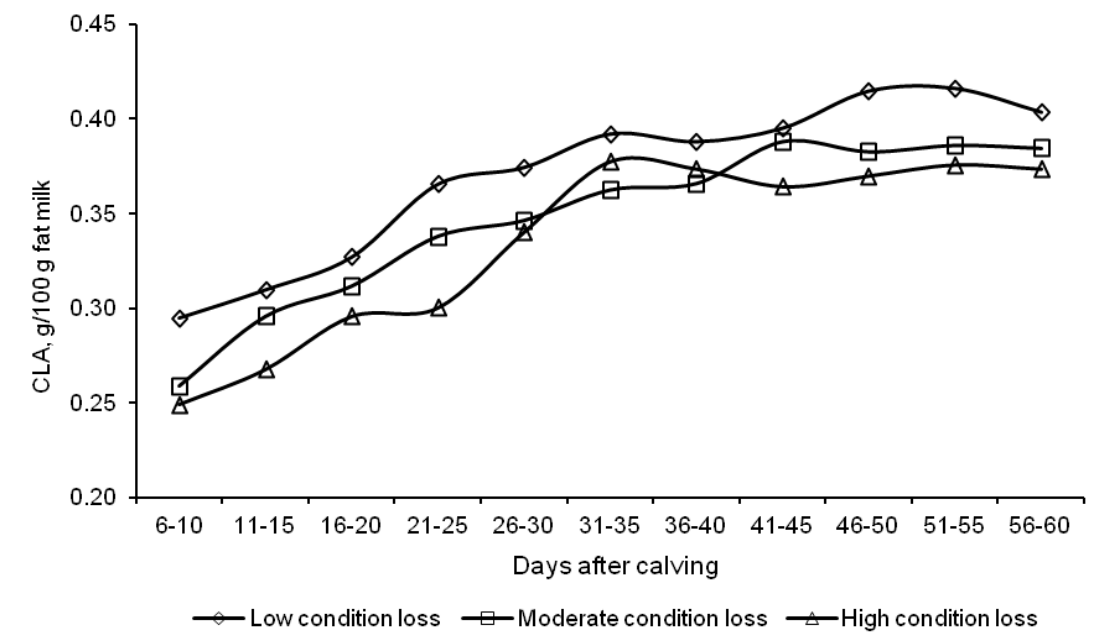

Figure 7. Changes in the conjugated linoleic acid (CLA) content of milk fat from d 6 to 60 of lactation. 
Table 5. The concentrations of fatty acids adversely affecting human health in milk fat from d 6 to 60 of lactation

\begin{tabular}{|c|c|c|c|c|c|c|}
\hline \multirow{2}{*}{ Fatty acid $\mathrm{g} / 100 \mathrm{~g}$ milk fat } & \multicolumn{2}{|c|}{ Low condition loss $(\mathrm{L})$} & \multicolumn{2}{|c|}{ Moderate condition (M) loss } & \multicolumn{2}{|c|}{ High condition loss $(\mathrm{H})$} \\
\hline & LSM & SE & LSM & SE & LSM & SE \\
\hline C 12:0 & $2.31^{\mathrm{a}}$ & 0.107 & $1.86^{\mathrm{b}}$ & 0.089 & $1.82^{\mathrm{b}}$ & 0.094 \\
\hline C 14:0 & $8.05^{\mathrm{A}}$ & 0.258 & $6.90^{\mathrm{B}}$ & 0.224 & $6.83^{\mathrm{B}}$ & 0.248 \\
\hline C 16:0 & $29.98^{\mathrm{a}}$ & 0.302 & $28.74^{\mathrm{b}}$ & 0.245 & $28.93^{\mathrm{b}}$ & 0.361 \\
\hline
\end{tabular}

Means within a row with different superscripts differ. ${ }^{\mathrm{A}, \mathrm{B}} \mathrm{p} \leq 0.01{ }^{\mathrm{a,b}} \mathrm{p} \leq 0.05$.

of TVA and OA in milk from group L cows were lower, compared with the other groups (Table 4). A significant difference to the advantage of group L cows was noted with respect to the levels of LNA, AA and DHA.

Cows characterized by low body fat mobilization, in comparison with cows of the remaining groups, produced milk with a significantly higher content of fatty acids having an adverse effect on human health (Table 5). The differences in the levels of myristic acid between groups $\mathrm{L}$ and $\mathrm{M}$, and $\mathrm{L}$ and $\mathrm{H}$ were significant ( $\mathrm{p}>0.01$ ), at $14.3 \%$ and $15.1 \%$, respectively. The proportion of saturated fatty acids C 12:0, 14:0 and 16:0 increased with progressing lactation (Figure 8).

\section{DISCUSION}

BCS at calving is positively correlated with a decrease in dry matter intake (Drackley 1999) and with BCS reduction after calving, and thus it is associated with the extent of NEB balance in early lactation (Berry et al., 2007). In our study, cows characterized by the highest drop in BCS (group H) already began to mobilize their fat reserves from 3 to 5 wks ap, while in the other cows the process started from 1 to 3 wks ap. The curves illustrating changes in BCS and BFT were similar, thus suggesting that a subjective assessment of body condition is a good indicator of the energy status of dairy cattle. Cows which mobilized approximately $11 \mathrm{~mm}$ subcutaneous fat (group M), and not $17 \mathrm{~mm}$ (group H), were characterized by the highest milk yield throughout lactation, which does not agree with the findings of Roche et al. (2009) who reported that body condition loss was positively correlated with milk production during lactation and peak milk yield. However, the cited authors analyzed cows producing 4,000 to 9,500 $\mathrm{kg}$ milk per lactation, kept in different systems and fed different diets. In our study, all cows were fed exclusively a TMR, and they produced nearly 13,000 milk per 305-d lactation on average. Under such conditions, the most intense mobilization of body energy reserves was not associated with the highest productivity, which could result from the fact that an excessive NEB makes the cow more susceptible to metabolic disorders (Santschi et al., 2011).

The fatty acid profile of milk is determined by shifts in the activity of fatty acid pathways (Stoop et al., 2009). Under severe NEB, the concentrations of short-chain and medium-chain fatty acids decrease, while the content of long-chain fatty acids increases. SFCA are an important source of energy for milk consumers as they are rapidly synthesized in the digestive tract and metabolized in the liver. Thus, they should have a high share of the total fatty acid pool. We found that high mobilization of body fat reserves adversely affected SFCA levels. The desirable, high UFA content of milk in groups $\mathrm{M}$ and $\mathrm{H}$ resulted from enhanced fat reserve mobilization and increased supply of non-esterified fatty acids (NEFA) to the udder. Gross et al. (2011) also observed a decrease in UFA concentrations in milk fat in successive weeks of lactation, as the energy balance improved. In our experiment, differences in MUFA

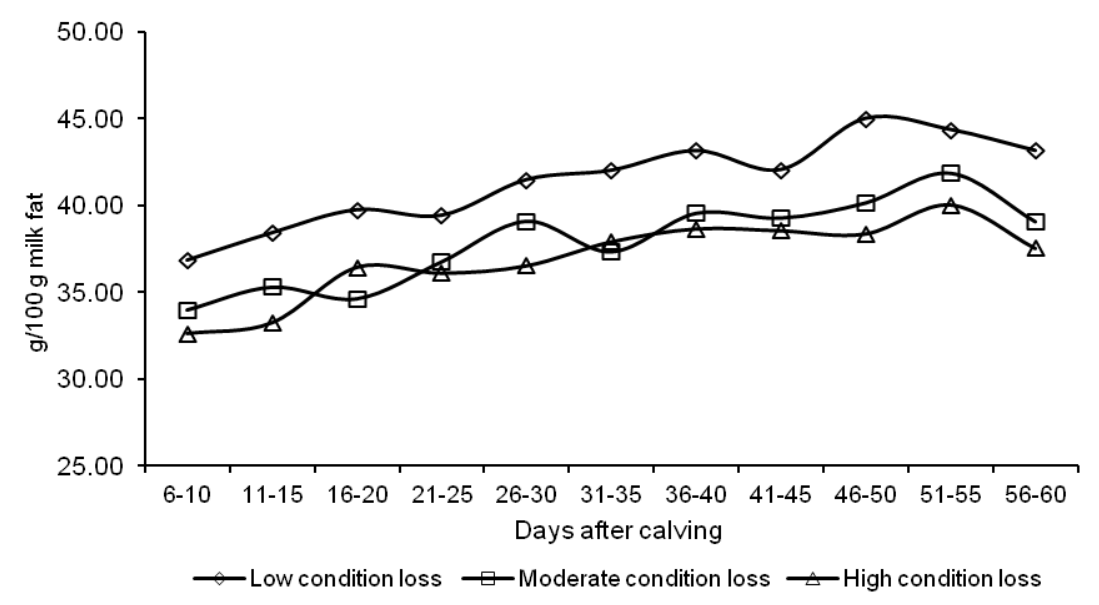

Figure 8. The concentrations of fatty acids adversely affecting human health in milk fat from d 6 to 60 of lactation. 
content were mostly due to the elevated levels of oleic acid in the milk fat of cows intensively mobilizing their body energy reserves. Oleic acid (C 18:1 cis 9) is the predominant FA in adipocytes. It is released primarily through lipolysis during NEB (Rukkwamsuk et al., 2000). Plasma NEFA and triglycerides are utilized by the mammary gland for milk FA synthesis (Gross et al., 2011). In the present study, a high transfer rate of oleic acid from plasma into milk fat was confirmed by an elevated proportion of $\mathrm{C} 18: 1$ cis 9 in the milk fat of group $\mathrm{M}$ and $\mathrm{H}$ cows. Long-chain FA are derived from plasma and incorporated into milk fat, and they inhibit de-novo synthesis of short-chain FA by the mammary gland (Palmquist et al., 1993). The observed increase in butyric acid with progressing lactation in the present study is consistent with the decreasing adipose tissue mobilization. Van Haelst et al. (2008) suggested that an elevated proportion of oleic acid may be an interesting trait for the prediction of subclinical ketosis, particularly since this FA was elevated in milk fat before diagnosis of ketosis. The correlation between energy balance and the proportion of $\mathrm{C}$ 18:1 cis 9 was 0.77 (Gross et al., 2011).

The elevated levels of n-3 fatty acids in milk from cows characterized by low mobilization of body fat reserves could be due to increased supply of LNA to the rumen. LNA acts a substrate for both TVA, which is converted to CLA, and long-chain fatty acids formed by further desaturation and elongation. In our study, the overall n-6/n3 fatty acid ratio was higher than recommended (Reklewska et al., 2002). The concentrations of n-6 fatty acids are higher in milk from cows fed a TMR, and so is the $n-6 / n-3$ fatty acid ratio (Nałęcz-Tarwacka, 2006).

The CLA content of milk fat increased with progressing lactation, with an improved energy balance, which corroborates the findings of Gross et al. (2011) who noted an increase in CLA levels in successive weeks of lactation in both cows fed a restricted ration (reduced energy intake) and control group cows.

Higher concentrations of lauric, myristic and palmitic acids in milk from cows with lower mobilization of body fat reserves, observed in our study, resulted from differences in the rate of fatty acid synthesis in the mammary gland. As demonstrated by Schroeder et al. (2003), the concentrations of lauric acid and myristic acid increased in milk from cows whose BCS improved by 0.1 on average in early lactation. This indicates that body fat reserve mobilization is associated with an increase in the share of UFA in the total fatty acid pool in milk, mostly due to a high supply of NEFA accompanied by a lower SFA content. According to Nałęcz-Tarwacka (2006), the proportion of fatty acids which adversely affect human health in the total fatty acid pool may be reduced through pasture grazing and avoiding mono diets.

\section{CONCLUSIONS}

Under conditions of high milk production, the highest mobilization of body energy reserves by cows with the highest BCS in the dry period was not accompanied by the highest productivity, which could result from their greater susceptibility to subclinical disease. Our findings do not indicate a clear association between high milk production and intensive feeding (TMR) and deterioration of the functional quality of milk fat. High mobilization of body fat reserves was associated with elevated levels of MUFA (mostly oleic acid), reduced concentrations of fatty acids adversely affecting human health and a decreased content of some functional fatty acids in milk. With progressing lactation, an improved energy balance contributed to a decrease in UFA concentrations and an increase in the CLA content of milk.

\section{REFERENCES}

Ayres, H., R. M. Ferreira, J. R. de Souza Torres-Júnior, C. G. B. Demétrio, C. G. de Lima and P. S. Baruselli. 2009. Validation of body condition score as a predictor of subcutaneous fat in Nelore (Bos indicus) cows. Livest. Sci. 123:175-179.

AOAC. 1990. Official methods of analysis of the Associated Official Analytical Chemists, Chepter 32, Washington, DC, USA.

Berry, D. P., F. Buckley and P. Diplom. 2007. Body condition score and live weight effects on milk production in Irish Holstein-Friesian dairy cows. Animal 1:1351-1359.

Drackley, J. K. 1999. Biology of dairy cows during the transition period: the final frontier? J. Dairy Sci. 82: 2259-2273.

Gross, J., H. A. van Dorland, R. M. Bruckmaier and F. J. Schwarz. 2011. Milk fatty acid profile related to energy balance in dairy cows. J. Dairy Res. 78:479-488.

Grummer, R. R., D. G. Mashek and A. Hayirli. 2004. Dry matter intake and energy balance in the transition period. Veterinary Clinics of North America-Food Animal Practice 20:447-470.

Ingvartsen, K. L. 2006. Feeding- and management-related disease in the transition cow: Physiological adaptation around calving and strategies to reduce feeding-related diseases. Anim. Feed Sci. Technol. 126:175-213.

Khanal, R. C. and T. R. Dhiman. 2007. Status of milk fat conjugated linoleic acid (CLA) in selected commercial dairies. Asian-Aust. J. Anim. Sci. 20:1525-1538.

Nałęcz-Tarwacka, T. 2006. Effect of selected factors on the functional component content of milk fat in dairy cows. Treatises and Monographs, Publications of Warsaw Agricultural University, p. 108.

Nogalski, Z. and E. Górak. 2008. Effects of the body condition of heifers at calving and at the first stage of lactation on milk performance. Med. Weter. 64:322-326.

Palmquist, D. L., A. D. Beaulieu and A. D. Barbano. 1993. Feed and animal factors influencing milk fat composition. J. Dairy Sci. 76:1753-1771.

Reklewska, B., A. Oprządek, Z. Reklewski, L. Panicke, B. Kuczyńska and J. Oprządek. 2002. Alternative for modifying 
the fatty acid composition and decreasing the cholesterol level in the milk of cows. Livest. Prod. Sci. 76:135-243.

Roche, J. R., N. C. Friggens, J. K. Kay, M. W. Fisher, K. J. Stafford and D. P. Berry. 2009. Invited review: Body condition score and its association with dairy cow productivity, health, and welfare. J. Dairy Sci. 92:5769-5801.

Rukkwamsuk, T., M. J. H. Geelen, T. A. M. Kruip and T. Wensing. 2000. Interrelation of fatty acid composition in adipose tissue, serum, and liver of dairy cows during the development of fatty liver postpartum. J. Dairy Sci. 83:52-59.

Santschi, D. E., D. M. Lefebvre, R. I. Cue, C. L. Girard and D. Pellerin. 2011. Incidence of metabolic disorders and reproductive performance following a short (35-d) or conventional (60-d) dry period management in commercial Holstein herds. J. Dairy Sci. 94:3322-3330.

Schroeder, G. F., J. E. Delahoy, I. Vidaurreta, F. Bargo, G. A. Gagliostro and L. D. Muller. 2003. Milk fatty acid composition of cows fed a total mixed ration or pasture plus concentrates replacing corn with fat. J. Dairy Sci. 86:3237-3248.

Schroeder, U. J. and R. Staufenbiel. 2006. Invited review: Methods to determine body fat reserves in the dairy cow with special regard to ultrasonographic measurement of backfat thickness. J. Dairy Sci. 89:1-14.
Sjaunja, L. O., B. Baevre, L. Junkkarinen, J. Pedersen and J. Setala. 1990. A Nordic proposal for an energy corrected milk (ECM) formula. Proc. 27th Session of the ICRPMA, Paris, July 2-6, 156-157.

Stoop, W. M., H. Bovenhuis and J. M. L. Heck. 2009. Effect of lactation stage and energy status on milk fat composition of Holstein-Friesian cows. J. Dairy Sci. 92:1469-1478.

Sumner, J. M. and J. P. McNamara. 2007. Expression of lipolytic genes in the adipose tissue of pregnant and lactating Holstein dairy cattle. J. Dairy Sci. 90:5237-5246.

Van Haelst, Y. N. T., A. Beeckman, A. T. M. van Knegsel and V. Fievez. 2008. Short communication: Elevated concentrations of oleic acid and long-chain fatty acids in milk fat of multiparous subclinical ketotic cows. J. Dairy Sci. 91:46834686.

Van Knegsel, A. T. M., H. van den Brand, H. J. Dijkstra, S. Tamminga and B. Kemp. 2005. Effect of dietary energy source on energy balance, production, metabolic disorders and reproduction in lactating dairy cattle. Reprod. Nutr. Dev. 45:665-688.

Wildman, E. E., G. M. Jones, P. E. Wagner, R. L. Boman, H. F. Troutt and T. N. Lesch. 1982. A dairy cow body condition scoring system and its relationship to selected production characteristics. J. Dairy Sci. 65:495-501. 